\title{
RESIKO OPERASIONAL UNIT TELLER DAN CUSTOMER SERVICE PADA PT. BPD SUMBAR CABANG PEMBANTU SIMPANG HARU
}

\author{
Ayu Santika Sari, Afriyeni \\ Akademi Keuangan Perbankan "Pembangunan" Padang \\ Email: ayusantikasari802@gmail.com
}

\begin{abstract}
This study aims to find out what Operational Risk will occur in the teller and customer service units at PT. BPD Sumbar Subsidiary branch of Simpang Haru. This research data collection method was collected from interviews with relevant units. The data analysis method in this study uses a descriptive method with an inductive mindset that explains the results of research about the facts that occur in the field which are then analyzed according to existing theories. Based on the results of this study found that PT. BPD Sumbar Subsidiary branch of simpang Haru has conducted monitoring and anticipation of operational risks that will occur in each work unit, especially in the teller and customer service units in order to avoid things that will damage the image and good name of the bank, because the teller and customer service units are merged front liner that will deal directly with customers. The monitoring and anticipation carried out by the bank prove the lack of unwanted events that will occur in the teller unit such as errors in inputting nominal and account numbers at the time of the transaction, underpayment or overpayment to customers, underpayment or excess when receiving customer deposit. As for the customer service unit such as incorrect input of customer data, complaints occur and others.
\end{abstract}

Keywords: operational risk, tellers and customer service.

\section{PENDAHULUAN}

Dunia perbankan mempunyai peranan penting dalam meningkatkan perekenomian suatu negara, apalagi dalam kehidupan masyarakat modern saat ini, yang sehari-hari melibatkan jasa sektor perbankan untuk melakukan semua transaksi. Dengan tingkat kepercayaan masyarakat terhadap perbankan terus meningkat ditandai dengan adanya peningkatan dana masyarakat ke sektor perbankan.

Bank merupakan badan usaha yang tugasnya menghimpun dana dari masyarakat dalam bentuk simpanan dan menyalurkan kembali kepada masyarakat dalam bentuk kredit untuk meningkatkan taraf hidup ekonomi masyarakat (Abdullah, 2014). Sedangkan menurut (Dahar, 2016) bank merupakan suatu lembaga keuangan yang dalam operasinya mengumpulkan dana dari masyarakat yang memiliki kelebihan dana dan menyalurkan dana tersebut berupa kredit kepada masyarakat yang membutuhkan dana.

Dalam bidang perbankan, pada 25 Mei 1960 pemerintah mendirikan Bank Pembangunan Daerah (BPD) ketentuanya diatur dalam UU No. 13/1962. Bank BPD didirikan dengan tujuan membantu melaksanakan pembangunan daerah yang merata ke seluruh daerah Indonesia. Bank Pembangunan Daerah mempunyai fungsi dalam perkembangan ekonomi, karena Bank Pembangunan Daerah memiliki banyak kantor pelayanan di setiap daerah. Saat ini ada 26 BPD di 
Indonesia, rata-rata setiap provinsi mempunyai satu BPD dan salah satunya Bank Pembangunan Daerah Sumatera Barat Cabang Pembantu Simpang Haru yang lebih dikenal dengan sebutan Bank Nagari Cabang Pembantu Simpang Haru, yang memiliki tujuan khusus untuk melayani nasabah dan pendorongan pada pertumbuhan perekonomian masyaratakat.

Bank Nagari Cabang Pembantu Simpang Haru memiliki perkembangan yang begitu pesat dan jumlah nasabah yang banyak, keadaan ini membuat aktifitas kerja pada Bank Nagari Simpang Haru semakin tinggi. Dengan semakin tinggi nya aktifitas kerja bank, kemungkinan terjadinya kesalahan atau resiko dari pekerjaan semakin tinggi, resiko operasional dapat di picu oleh berbagai faktor baik internal maupun external, seperti kegagalan system informasi, kegagalan jaringan, rusaknya alat kerja dan kejahatan dari pihak external terhadap Bank yang. Risiko operasional tidak dapat dihindarkan tetapi bisa di minimalkan, oleh karena itu semua pihak yang terlibat dalam bank harus mengerti dengan resiko operasional agar semua pihak yang terlibat di dalam bank bisa berhati-hati dengan resiko operasional, tidak menutup kemungkinan terjadi pada bagian teller dan customer service karena resiko operasional yang terjadi pada bagian ini tidak berdampak lansung dengan kondisi keuangan bank, tetapi berdampak lansung dengan kualitas pelayanan dan nama baik bank.

Teller adalah seseorang pihak bank yang bertugas melayani nasabah atau customer dalam hal transaksi keuangan kepada semua nasabah nya (Handayani, 2017). Menurut Amelia, ( 2017 ) teller bertanggung jawab atas transaksi tunai terutama atas penerimaan maupun pembayaran uangnya atau petugas-petugas yang berkerja di unit kerja kas dinamakan kasir atau teller yang dipakai oleh kepala kas. Berdasarkan keterampilan prestasi kerja, senioritas masing-masing petugas dan penjabat dilingkungan unit kerja kas dilimpahi tugas dan wewenang yang berbeda-beda. kelalaian yang sering terjadi pada unit teller bank yaitu selisih kas, jangguan jaringan dan lainnya.

Customer Service secara umum ialah setiap kegiatan yang di peruntukan atau di tujukan untuk memberikan kepuasan kepada nasabah, melalui pelayanan yang dapat memenuhi keinginan dan keutuhan nasabah (Afriyeni, 2014) Contoh kelalaian yang dilakukan oleh customer service seperti, salah mendaftarkan nomor seri buku Cek, salah memasukkan data nasabah, salah memprint buku tabungan nasabah yang mengakibatkan buku tersebut rusak, kelalaian customer service dalam melayani nasabah yang menimbulkan adanya complain dari nasabah. Oleh karena itu Bank Nagari Capem Simpang Haru dituntut untuk mampu secara efektif mengelola risiko operasional yang akan dihadapinya untuk mengatasi kemungkinan terjadinya kerugian dari segi keuangan atau nama baik bank, akibat dari risiko operasional tersebut.

Berdasarkan latar belakang permasalahan di atas, maka penulis tertarik melakukan penelitian dalam bentuk Tugas Akhir dengan judul: "Risiko Operasional Unit Teller dan Customer Service pada PT. BPD Sumbar Cabang Pembantu Simpang Haru“. 


\section{METODE PENELITIAN}

\section{Metode Pengumpulan Data}

1. Studi Lapangan

Pada penelitian ini dilakukan dengan cara melakukan wawancara dengan pihak-pihak PT. Bank Pembangunan Daerah Sumatera Barat.

2. Studi Kepustakaan

Penelitian ini dilakukan dengan mengumpulkan data dan menggunakan teori-teori yang berkaitan dengan masalah-masalah yang akan dibahas, berupa buku-buku yang berkaitan dengan masalah.

\section{Metode Analisa Data}

Metode analisa data yang digunakan dalam penelitian ini adalah Metode Analisis Kualitatif yang menjelaskan secara deskriptif yaitu dengan merincikan data secara sistematis dari informasi yang didapat kemudian dihubungkan dengan Risiko Operasional Unit Teller dan Customer Service pada Bank Nagari Cabang Pembantu Simpang Haru.

\section{ANALISA DAN PEMBAHASAN \\ Gambaran Manajemen Risiko Operasional Pada Unit Teller dan Customer Service.}

Bank akan memberikan pelayanan yang terbaik dan menjadi bank kebanggaan bagi masyarakat serta unggul dalam layanan dan kinerja.Untuk itu bank akan meningkatkan kualitas nya dan memperhatikan risiko operasional pada unit teller dan unit customer service karena teller dan customer service merupakan Front Liner dimana didalam kegiatan operasional nya, akan berinteraksi lansung dengan nasabah. oleh karena itu customer service dan teller dituntut untuk memberikan pelayanan prima sepenuh hati terhadap seluruh nasabah yang datang ke bank.

Teller adalah tugas dari seseorang pihak bank yang bertugas untuk melayani nasabah atau customer dalam hal transaksi keuangan perbankan kepada semua nasabahnya (Handayani, 2017). Menurut (Amelia, 2017) menyatakan bahwa Teller bertanggung jawab atas transaksi tunai terutama atas penerimaan maupun pembayaran uangnya.

Teller bertanggung jawab atas transaksi tunai terutama dalam penerimaan maupun pembayaran uangnya, petugas yang bekerja diunit kerja kas disebut dengan kasir atau teller yang dipakai oleh kepala kas. Berdasarkan keterampilan prestasi kerja, senioritas masing-masing petugas dan penjabat dilingkungan unit kerja kas di limpahi tugas dan wewenang yang berbeda-beda. Tugas-tugas teller di bedakan menjadi beberapa kelompok antara lain yang berhubungan dengan:

1. Persediaan uang tunai

Bank memelihara persediaan uang tunai dalam berbagai macam jenis persediaan, yang dapat dibedakan menjadi 2 golongan yaitu persediaan umum yang menjadi tanggung jawab kepala teller dibawah pengendaliaan kepala bagian operasional dan persediaan yang disimpan dalam kontak kasir (teller).

2. Penerimaan setoran 
Sumber utama persediaan uang tunai merupakan penerimaan setoran melalui nasabah apabila terjadi suatu kekurangan atau melewati batas minimum persediaan bank harus menarik dari bank indonesia atau bank lain.

a. Pembayaran uang tunai

Persedian uang tunai oleh bank disalurkan melalui pembayaran tunai

kepada nasabah dan pembayaran tunai lain. Setiap teller melakukan pembayaran tunai sesuai dengan limit atau tingkat kewenangannya masingmasing.

Customer Service adalah seorang petugas barisan terdepan atau front liner yang di tugaskan untuk melayani nasabah, tujuan customer service ialah memberikan pelayanan sepenuh hati kepada nasabah, baik itu untuk pembuatan rekening tabungan nasabah sampai menyelesaikan komplain nasabah.

Customer Service juga mempunyai tanggung jawab atas aktivitas hariannya, yang di awali dengan dibukanya pintu khasanah, customer service yang mendapat wewenang untuk masuk ke dalam khasanah akan melakukan serah terima cashbox kepada masing-masing customer service yang tanggung jawab atas isi dari masing-masing cashbox. Cashbox tersebut berisi antara lain (Afriyeni, 2015):

1. Buku tabungan

2. Kartu ATM

3. Buku cek, bilyet giro

4. Bilyet Deposito

\section{Pengertian Risiko}

Menurut (Leviza, 2014) risiko tidak cukup untuk dihindari tetapi harus dihadapi juga dengan cara-cara yang dapat memperkecil kemungkinan terjadinya suatu kerugian, maka dari itu risiko harus dikelola dengan baik dan benar. Sedangkan menurut (Hanafi, 2014) Risiko adalah di mana kemungkinan kerugian ada, tetapi kemungkinan keuntungan tidak ada.

\section{Jenis-Jenis Risiko Bank}

Didalam setiap aktivitas bank sebagai lembaga intermediary, bank menghadapi banyak jenis risiko. Ditambah lagi dengan kemajuan bank yang cukup pesat dan jumlah nasabah yang banyak, maka kemungkinan terjadinnya resiko tidak dapat untuk dihindarkan. Jenis-jenis risiko yang dihadapi oleh bank saat ini adalah :

a. Risiko Kredit

Risiko yang terjadi akibat kegagalan pihak debitur atau pihak lawan untuk memenuhi kewajibannya kepada bank. Risiko kredit dapat bersumber dari aktivitas fungsional bank, seperti perkreditan atau penyediaan dana, treasury dan investasi dan pembiayaan perdagangan yang tercatat baik dalam pembukuan bank maupun buku dealer .

Risiko ini merupakan antisipasi atas aliran kas masa mendatang, dan karena itu risiko kredit akan sangat mempengaruhi likuitas bank mengingat kegagalan debitur dalam menunaikan kewajibannya akan menimbulkan kerugian bangi bank melalui pembentukan cadangan penghapusan piutang atau penghapus bukuan. 
b. Risiko Pasar

Potensi kerugian yang timbul akibat:

1) Suku Bunga

Pergerakan suku bunga di pasar yang berlawanan dengan posisi atau transaksi bank yang mengandung risiko suku bunga.

2) Harga Perubahan harga fortofolio instrumen keuangan saham, surat-surat berharga dan pasdar-pasar komoditi yang diperdagangkan.

3) Valuta asing Pergerakan nilai tukar yang berlawanan dengan nilai tukar pada saat bank memiliki posisi terbuka.

c. Risiko Likuiditas

Risiko yang antara lain disebabkan bank tidak mampu memenuhi kewajiban yang telah jatuh tempo dengan kategori sebagai berikut :

1) Risiko likuiditas pasar, yaitu risiko yang timbul sehubungan dengan fungsi bank sebagai intermediasi dimana bank tidak mampu melakukan offsetting posisi tertentu karena kondisi likuiditas pasar yang tidak memadai atau terjadi gangguan di pasar

2) Risiko likuiditas pendanaan, yaitu risiko yang timbul karena bank tidak mampu mencairkan asetnya dan atau memperoleh pendanaan dari sumber dana lain.

d. Risiko Operasi

Risiko yang antara lain disebabkan adanya ketidakcukupan dan atau tidak berfungsinya proses internal, kejahatan, kesalahan manusia, kegagalan sistem, ketidak mampuan menyerahkan produk atau jasa, mempertahankan proses persaingan, mengelola informasi atau adanya problem eksternal yang mempengarui operasional bank.

e. Risiko Kepatuhan

Risiko yang disebabkan bank tidak memenuhi atau tidak melaksanakan peraturan perundang-undangan dan ketentuan lainya yang berlaku, termasuk standar etika. Risiko kepatuhan dapat menimbulkan buruknya reputasi dan terbatasnya peluang bisnis.

f. Risiko Strategis

Risiko yang antara lain disebabkan adanya penetapan dan pelaksanaan strategi bank yang tidak tepat, pengambilan keputusan bisnis yang tidak tepat atau bertentangan atau kurang responnya bank terhadap perubahan eksternal. Risiko ini merupakan fungsi kesesuaian dari sasran strategis eksternal, strategis bisnis yang dikembangkan dan sumber daya yang digunakan untuk mencapai sasaran tersebut dan kualitas implementasinya.

g. Risiko Reputasi

Risiko akibat menurunnya tingkat kepercayaan nasabah, masyarakat, manajemen bank dan pegawai yang bersumber dari persepsi negatif terhadap bank. Diantara risiko yang dihadapi bank, risiko reputasi merupakan risiko yang memiliki dampak paling signifikan dan dapat mempengaruhi kelansungan usaha bank.

h. Risiko Hukum

Risiko yang disebabkan oleh adanya kelemahan aspek yuridis, antara lain: adanya tuntutan hukum, ketiadaan peraturan perundang-undangan yang 
mendukung atau kelemahan perikatan seperti tidak terpenuhinya syarat sah kontrak seperti syarat subyektif dan syarat objektif dan pengikatan yang tidak sempurna.

i. Risiko Produk dan Aktivitas Baru

Risiko yang disebabkan kegagalan pelaksanaan pelayanan dan atau penjualan produk dan aktivitas bank yang baru dimana pada lazimnya akan terkait dengan satu atau lebih jenis-jenis risiko yang diuraikan diatas.

\section{Ruang Lingkup Manajemen Risiko Bank}

Dewan direksi dari tiap bank mempunyai tugas untuk menetapkan bahwa risiko perbankan dalam menjalankan bisnis diatur dalam suatu tata cara yang efektif. Dalam pelaksanaan tugas tersebut membutuhkan :

a. Pengawasan aktif dari dewan komisaris, direksi dan personal manajemen risiko yang terkait yang dipilih oleh bank.

b. Penetapan kebijakan dan prosedur untuk menentukan batas untuk risiko yang dilaksanakan oleh bank.

c. Penetapan prosedur untuk mengidentifikasi, mengukur, memantau dan mengendalikan risiko.

d. Penetapan dari suatu struktur pengawasan intern untk mengatur risiko.

\section{Pengertian Risiko Operasional Bank}

Risiko operasional Bank merupakan salah satu permasalahan yang sudah sering terjadi yang harus di jadikan perhatian, hal ini dipicu oleh adanya sejumlah kejadian yang dialami oleh lembaga keuangan yang akan berdampak buruk bagi Bank. Risiko operasional bisa menimbulkan sebuah kerugian keuangan maupun kerugian lainnya seperti tercoreng nya nama baik bank yang akan mengakibatkan nasabah berpindah ke bank lainnya.

Resiko Operasional adalah risiko yang disebabkan ketidak cukupan atau tidak berfungsinnya proses internal, kesalahan manusia, kegagalan system, atau adanya problem external yang mempengaruhi operasional Bank.

Bank For International Settlement 1 (BIS) memberikan definisi tentang resiko operasional, Resiko Operasional adalah resiko kerugian yang dapat terjadi baik lansung maupun tidak lansung yang di sebabkan oleh ketidak cukupan atau kegagalan daro peroses internal, orang, system atau sebab dari luar. Risiko operasional memiliki pengaruh langsung terhadap sumber daya manusia yang berhubungan dengan karyawan yang bekerja disuatu bank, terutama yang berhubungan lansung dengan nasabah salah satunya adalah teller dan Costumer Service.

\section{Faktor-faktor Yang Mengakibatkan Terjadinnya Risiko Operasioanl Unit Teller Dan Customer Service}

Adapun Faktor-fakor yang mengakibatkan terjadinya risiko operasional pada unit teller dan customer service yaitu:

a. Faktor kelelahan yang mengakibatkan kurang nya konsentrasi kerja.

b. Faktor internal seperti, kegagalan jaringan, salah input data nasabah, rusak nya alat kerja dan lainnya.

c. Faktor external seperti kesalahan yang di perbuat oleh nasabah atau kejahatan lainnya. 


\section{Potensi Risiko Operasional Unit Teller dan Unit Customer Service}

Unit teller dan customer service mempunyai potensi risiko operasional yang tinggi karena berhubungan langsung dengan nasabah yang ingin melakukan transaksi baik melalui teller maupun melalui customer service, kesalahan yang sering terjadi pada risiko operasional unit teller dan customer service yaitu kesalahan dalam pengimputan data .

Beberapa potensi risiko yang dapat terjadi pada unit Teller

1. Risiko adanya uang palsu.

2. Kesalahan dalam penginputan nominal dan nomor rekening pada saat transaksi.

3. Kekurangan atau kelebihan bayar kepada nasabah.

4. Kekurangan atau kelebihan pada saat menerima setoran nasabah.

5. Risiko terjadinya salah pemindahbukuan / input mutasi.

Adapun potensi risiko yang dapat terjadi pada unit customer service.

1. Salah input data nasabah.

2. Complain nasabah.

Oleh sebab itu setiap bank memiliki kebijakan dan prosedur pengendalian dan mitigasi risiko operasional yang dipatuhi dan dilaksanakan oleh unit teller dan customer service.

\section{Prosedur Mengidentifikasi Risiko Operasional Unit Teller}

Prosedur mengidentifikasi Risiko Operasional pada unit teller dapat dilihat pada aktifitas harian yang dilakukan sesuai dengan SOP dan prosedur yang telah ditetapkan, namun PT. Bank Pembangunan Daerah Sumatera Barat menggunakan prosedur manajemen risiko operasional pada unit teller dilakukan dengan mengikuti sistem dan prosedur yang telah ditetapkan oleh pihak manajemen, prosedur manajemen risiko operasional ini dilakukan untuk menghindari terjadinya risiko selisih pada kas.

Dimulai pada pagi hari dimana manager teller yang mendapat wewenang untuk masuk khasanah akan melakukan serah terima cashbox kepada masingmasing teller yang bertanggung jawab sepenuhnya atas isi masing-masing cashbox. Isi Cashbox tersebut, yaitu : uang tunai pecahan kecil yang tidak dapat disetorkan kepada head teller pada akhir hari sebelumnya.

\section{Prosedur Mengidentifikasi Risiko Operasional Unit Customer Service}

Pada unit Customer Service prosedur mengidentifikasi resiko operasional unit customer service di lihat dari aktivitas harian yang dilakukan. Dimulai dari pagi hari setelah dibukanya pintu khasanah, Head Customer Service yang berwenang untuk masuk ke dalam khasanah, setelah itu customer service akan melakukan serah terima cashbox kepada masing-masing Customer Service yang diberi tanggung jawab atas isi dari masing-masing cashbox. Cashbox tersebut berisi antara lain (Afriyeni, 2015) :

1. Buku tabungan

2. Kartu ATM

3. Buku cek, bilyet giro

4. Bilyet Deposito 


\section{Antisipasi yang dilakukan Bank Nagari Cabang Pembantu Simpang Haru}

Dalam mengantisipasi kerugian yang mungkin timbul dari risiko operasional, Bank Pembangunan Daerah Sumatera Barat telah melakukan beberapa tindakan antisipatif yang meliputi :

a. Sandi (password)

Masing-masing user memiliki password yang digunakan untuk masuk dan "login" pada sistem yang akan digunakan untuk menjalankan kegiatan operasional sehari-hari. Password ini akan habis masa berlakunya dalam jangka waktu empat belas hari. Untuk itu user wajib mengganti password tersebut sebelum habis masa berlakunya. Hal ini sangat membantu pengendalian terhadap risiko penyalahgunaan password.

b. Pemisahan Wewenang dan Tanggung Jawab

Terdapat beberapa pemisahan wewenang dan tanggung jawab dalam hal :

1) Pemegang kunci dan kode kombinasi khasanah, di mana :

a) Authorized Signer memegang kunci brankas uang.

b) Supervisor memegang kunci pintu besi luar dan teralis

c) Manager Operasional memegang kode kombinasi pintu besi luar dan kode kombinasi brankas uang.

2) Pemegang kunci dan kode kombinasi ruang Safe Deposit Box, di mana :

a) Customer Service memegang kunci master box.

b) Head CS memegang kunci pintu teralis dalam.

c) Supervisor memegang kunci pintu besi luar.

d) Manager Operasional memegang kode kombinasi pintu besi luar.

3) Pemegang kunci dan kode kombinasi mesin ATM, di mana :

a) Head teller memegang kunci pintu brankas ATM.

b) Supervisor memegang kode kombinasi pintu brankas ATM.

Hal ini dilakukan dengan maksud agar terdapat dual control dan memperkecil kemungkinan terjadinya penyalah-gunaan wewenang dan tanggung jawab.

\section{SIMPULAN}

1. Kegiatan operasional merupakan kegiatan yang tidak dapat dipisahkan dari sebuah perusahaan, tanpa kegiatan operasional perusahaan tidak akan dapat menjalankan aktivitasnya, dalam menjalankan aktivitas kerja kemungkinan terjadinnya risiko sangat besar, karena di dalam setiap aktivitas kerja terdapat resiko seperti risiko internal dan risiko external.

2. Unit teller dan customer service mempunyai potensi risiko operasional yang tinggi karena berhubungan langsung dengan nasabah karena kesalahan yang terjadi akan mengakibatkan kerugian baik finance maupun non finance seperti nama baik bank.

3. Faktor-fakor yang mengakibatkan terjadinya risiko operasional pada unit teller dan customer service yaitu:

a. Faktor kelelahan yang mengakibatkan kurang nya konsentrasi kerja.

b. Faktor internal seperti, kegagalan jaringan, salah input data nasabah, rusak nya alat kerja dan lainnya. 
c. Faktor external seperti kesalahan yang di perbuat oleh nasabah atau kejahatan lainnya.

4. Adapun Prosedur Mengidentifikasi Risiko Operasional Unit Teller

Prosedur mengidentifikasi Risiko Operasional pada unit teller dapat dilihat pada aktifitas harian yang dilakukan sesuai dengan SOP dan prosedur yang telah ditetapkan, namun PT. Bank Pembangunan Daerah Sumatera Barat menggunakan prosedur manajemen risiko operasional pada unit teller dilakukan dengan mengikuti sistem dan prosedur yang telah ditetapkan oleh pihak manajemen, prosedur manajemen risiko operasional ini dilakukan untuk menghindari terjadinya risiko selisih pada kas.

5. Pada unit Customer Service prosedur mengidentifikasi resiko operasional unit customer service di lihat dari aktivitas harian yang dilakukan. Dimulai dari pagi hari setelah dibukanya pintu khasanah, Head Customer Service yang berwenang untuk masuk ke dalam khasanah, setelah itu customer service akan melakukan serah terima cashbox kepada masing-masing Customer Service yang diberi tanggung jawab atas isi dari masing-masing cashbox.

6. Bank Nagari Cabang Pembantu Simpang Haru melakukan beberapa tindakan antisipatif yang meliputi :

a. Pemberian Sandi (password) pada setiap computer dan aplikasi yang di pakai Bank Nagari Capem Simpang Haru.

b. Memberi kunci dan kode kombinasi ruang Safe Deposit Box.

c. Memberi kunci dan kode kombinasi mesin ATM.

\section{UCAPAN TERIMA KASIH}

Penulis ucapkan puji dan syukur atas kehadirat-Nya, yang telah melimpahkan rahmat dan hidayah kepada penulis. Penulis ingin mengucapkan terima kasih yang tak terhingga atas bimbingan Ibu Afriyeni, SE, MM yang telah memberikan motivasi, masukan-masukan yang bermanfaat bagi penulis dan terima kasih untuk teman-teman atas semangat dan dukungannya dalam pembuatan artikel ini. Akhir kata penulis ucapkan terima kasih, semoga apa yang penulis tuangkan dalam karya kecil ini memberikan manfaat terutama bagi saya sendiri selaku penulis. Amin ya Rabbal'alamin.

\section{DAFTAR PUSTAKA}

Abdullah, T. (2014). Pengertian dan Sejarah Singkat Perbankan di Indonesia. Buku Lembaga Keuangan, 4-5.

Afriyeni, A. (2014). penerapan manajemen resiko operasional pada PT.Bank Pembangunan Daerah Sumatera Barat Cabang Painan. 1-14.

Afriyeni, A. (2015). Implementasi Manajemen Resiko operasional pada unit Customer Service dan Teller di PT.Bank Rakyat Indonesia(persero)Tbk.Cabang Padanf. 1-86.

Amelia, T. R. (2017). Tinjauan Service Excellent Teller Pada Bank Nagari Siteba. Sripsi Kementrian Riset Teknologi Dan Pendidikan Tlinggi Politeknik Negri Padang, 6-7.

Dahar, R. (2016). Analisis Tingkat Kesehatan Bank Dengan Menggunakan Model Risk-Based Bank Rating (RBBR) (Studi Pada Perbankan Yang Listing di 
Bursa Efek Indonesia Periode 2011-2014). Jurnal Menara Ilmu, X(73), 12.

Hanafi, M. M. (2014). Risiko, Proses Manajemen Risiko, dan Enterprise Risk Management. Book Manajemen Risiko, 1-40. https://doi.org/10.1016/j.ejogrb.2009.08.001\rS0301-2115(09)00488-6 [pii]

Handayani, P. R. (2017). Peningkatan Kualitas Layanan Teller Guna Mencapai Kepuasan Nasabah Pada PT Bank Rakyat Indonesia (PERSERO) TBK, Unit Teluk Dalam Banjarmasin Novi. I, 31-32.

Leviza, J. (2014). Peranan Manajemen Risiko Dalam Tugas Dan Tanggung Jawab Direksi Bank Berdasarkan Peraturan Perundang-undangan Di Indonesia. Jurnal USU Law Journal, Vol.II-No.1, 1(1), 22-25.

Romi susanto. (2018). Penerapan Manajemen Risiko Operasional Pada Unit Teller Pada PT . Bank Pembangunan Daerah Sumatera Barat Cabang Lubuk Alung. 13, 1-10.

Safitri, R. N., \& Marlius, D. (2017). Penerapan E-Banking Dalam Meningkatkan Jasa Dan Layanan Perbankan Di PT. Bank Rakyat Indonesia Cabang Padang. https://doi.org/10.31227/osf.io/gkv8t. 